\title{
SOURCES OF SPATIAL INFORMATION ABOUT NOISE AS EXEMPLIFIED BY THE SPATIAL INFORMATION SYSTEM (SIS) IN POZNAŃ
}

\author{
JAROSŁAW KUBIAK \\ Adam Mickiewicz University in Poznań, \\ Department of Cartography and Geomatics, \\ ul. Bogumiła Krygowskiego 10, 61-680 Poznań
}

\begin{abstract}
Noise is subject to compulsory mapping. Access to environmental acoustical data should be available to the public user. These tasks result directly from the provisions of the Environmental Protection Law Act - EPL Act. The method of their implementation is presented using the example of the Poznan Spatial Information System. Available data sources are indicated, mainly in relation to cartographic visualisation of the presented contents.
\end{abstract}

Keywords: noise mapping, environmental information, thematic cartography

\section{INTRODUCTION}

Noise, due to its prevalence and recorded values, is currently considered to be one of the greatest threats to the environment of human life (European Commission 2014). This problem is particularly acute in urban and industrialised areas (Passchier-Vermeer, Passchier 2000; Garcia 2001; Goines, Hagler 2007). Despite the prevalence of the phenomenon, its negative effects are still underestimated or downplayed. Due to health impacts (Czeskin 1986; Koszarny, Szata 1987; Koszarny 1999; Babisch 2005; Zannin et al. 2006; Allen et al. 2009; Leśnikowska-Matusiak, Wnuk 2014), but also economic effects (WHO 2005; Stevens 2012), caused by noise, this issue has become one of the topics of the European environmental protection policy (Halama, Berkemann 2009).

In order to prevent and tackle the negative effects of environmental noise, the European Parliament adopted a document - Directive 2002/49/EC of the European Parliament and of the Council of 25 June 2002 (END 2002), the aim of which is to assess exposure to noise and propose a uniform approach to this hazard in all member states of the European Union.

One of the requirements of the Directive is to develop, depending on the purpose of use, a set of different noise maps - among others they are to be drawn up in order to inform the public about this hazard. They are also the basis for further planning and protective work (Kompała 2005; King, Rice 2009). 
The objective of the Directive is to define a common approach to avoiding, preventing or reducing the harmful effects, including nuisance, of exposure to noise through the following measures:

- determination of environmental noise exposure through noise mapping, using common assessment methods;

- ensuring that the public has access to information on environmental noise and its effects;

- the adoption, on the basis of data from noise maps, of action plans to prevent and reduce environmental noise in conflict areas and to preserve the quality of the acoustic climate in areas without noise pollution.

A legal requirement for noise mapping has therefore arisen. In addition, the Directive regulates public information, data collection and publication as well as reporting and analysis.

Under Article 3 of the Directive "noise mapping" shall mean the presentation of data on an existing or predicted noise situation in terms of a noise indicator, indicating breaches of any relevant limit value in force, the number of people affected in a certain area, or the number of dwellings exposed to certain values of a noise indicator in a certain area.

The regulations resulting from this Directive have mostly been transposed into Polish law by the Act of 27 April 2001 - Environmental Protection Law (Journal of Laws 2013). Regulation of the Minister of the Environment of 1 October 2007 (Journal of Laws 2007), enacted to the EPL Act, defines the scope of data included in acoustic maps and their layout and manner of presentation in order to use them for:

- informing the public about noise pollution;

- development of data for national environmental monitoring;

- creating and updating programmes for the protection of the environment against noise.

Annex 3 to the Regulation lists four mandatory studies, which are covered by the graphic part of the acoustic map used to inform the public:

1. emission maps - they characterise noise emitted from particular sources identified in a given area (Fig. 1);

2. area noise sensitivity map - presents the distribution of permissible (specified in the relevant regulation) noise levels in the area under consideration, depending on the land use and its functions, with reference to the Local Zoning Plan (LZP) or other planning documents (Fig. 2);

3. noise endangered areas map - shows isolines of exceeding the permissible value of the indicator (Fig. 3);

4. immission map - shows the acoustic state of the environment formed by a given type of noise source (Fig. 4).

In accordance with formal requirements, individual noise sources are presented on separate maps and are expressed using long-term $L_{\mathrm{DWN}}$ and $L_{\mathrm{N}}$ indicators. 


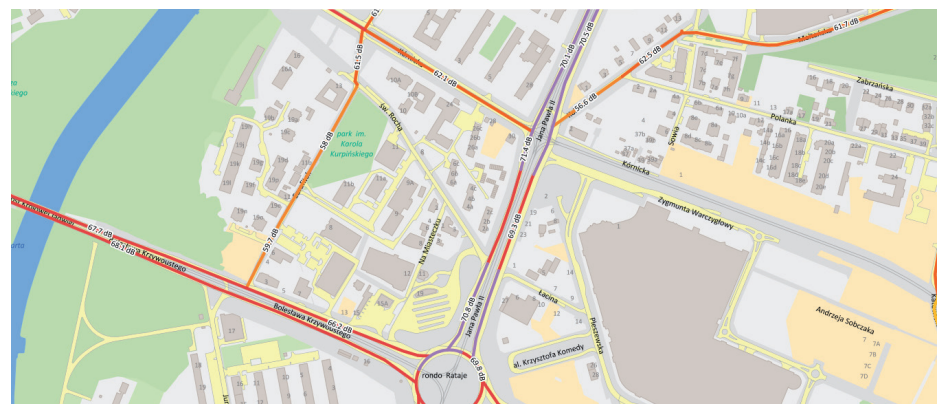

Fig. 1. Road noise emission - fragment (source: SIP Poznań)

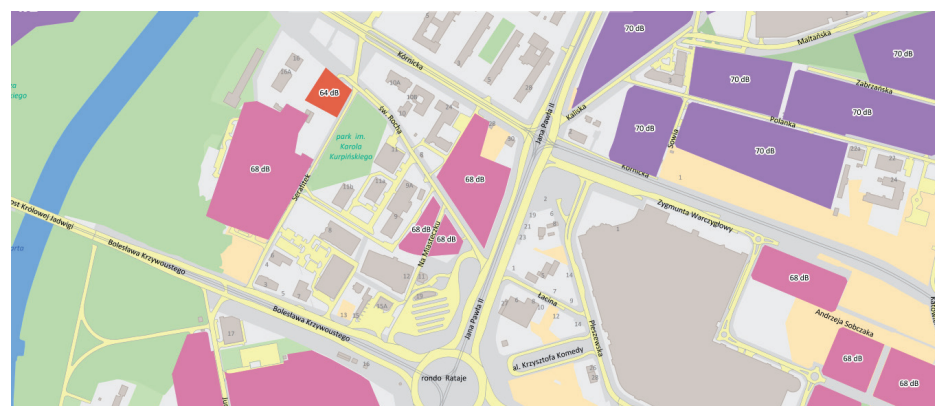

Fig. 2. Noise sensitivity of the area - fragment (source: SIP Poznań)

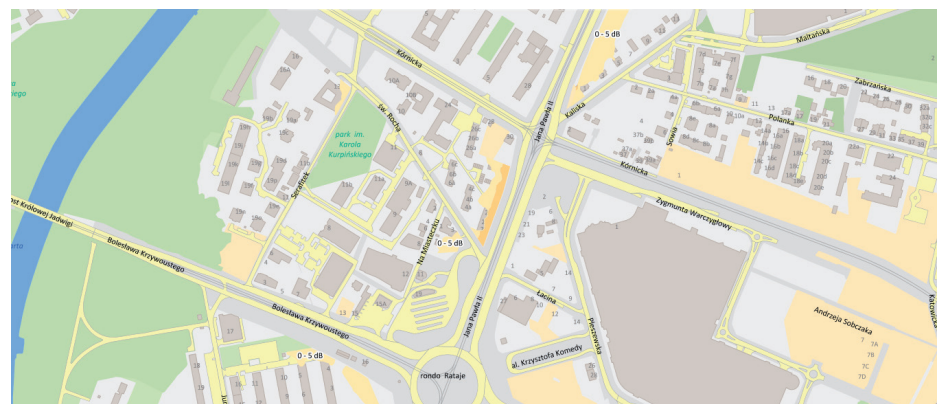

Fig. 3. The areas at risk of road noise - fragment (source: SIP Poznań)

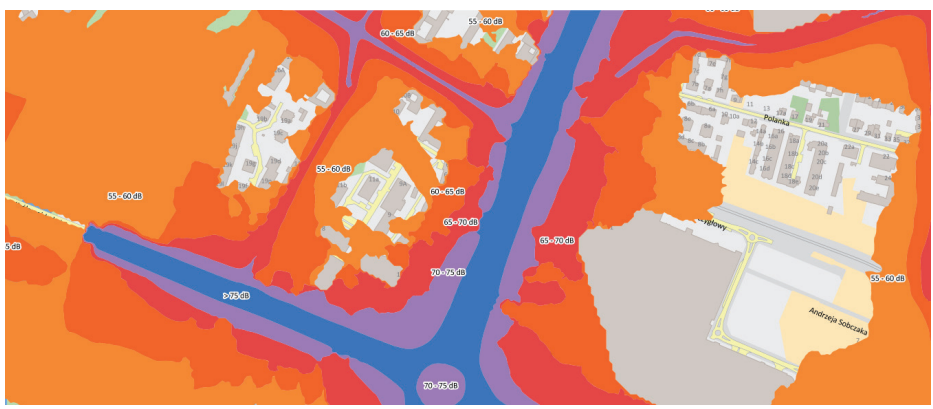

Fig. 4. Road noise immission - fragment (source: SIP Poznań) 


\section{IMPLEMENTATION OF GUIDELINES CONTAINED IN LEGAL DOCUMENTS}

The most common and, at the same time, the most popular way to quickly access, view and download spatial data is to use network tools.

In the case of Poznań, the statutorily required universal access to spatial data, including noise, is achieved through the Municipal Multimedia Guide, which is the official medium of the City Hall in Poznań. It offers, among others, thematic services, including the "Poznan Environmental Protection Service", which contains information on noise. Using this guide, it is best to select the alphabetic "A-Z Catalogue" and select the "Environment" tab from this level. The website of the Environmental Protection Department (epd) will be opened, from where one should enter the tab "Noise in the environment" (Fig. 5). The following links are available: Introduction, Acoustic Map 2007, Program 2008, Acoustic Map 2012, Program 2013 and Acoustic Map 2017. In the tabs concerning acoustic maps from 2007, 2012 and 2017 there are active links, which indirectly (through the website of the Geodesy and Municipal Cadastre of GEOPOZ) or directly direct the user to the Spatial Information System. This location can also be reached directly from the GEOPOZ website through the tab "Interesting facts" and then the "Spatial Information System" (Fig. 6).

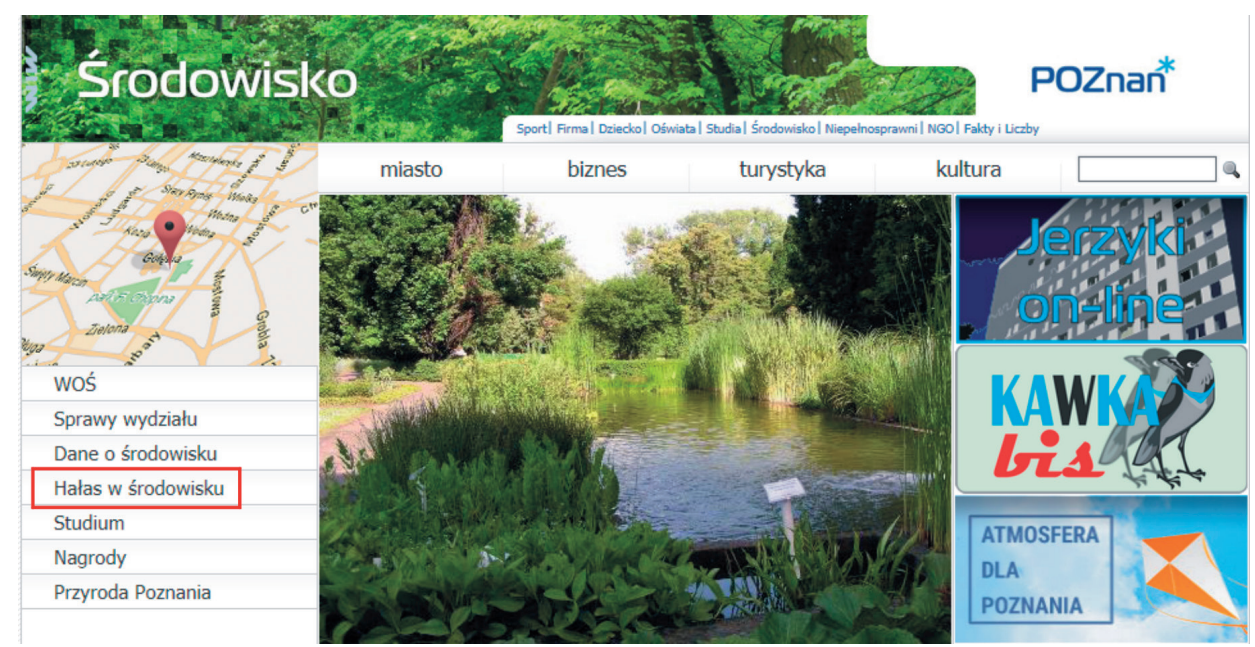

Fig. 5. Website of the Department of Environmental Protection in Poznań 


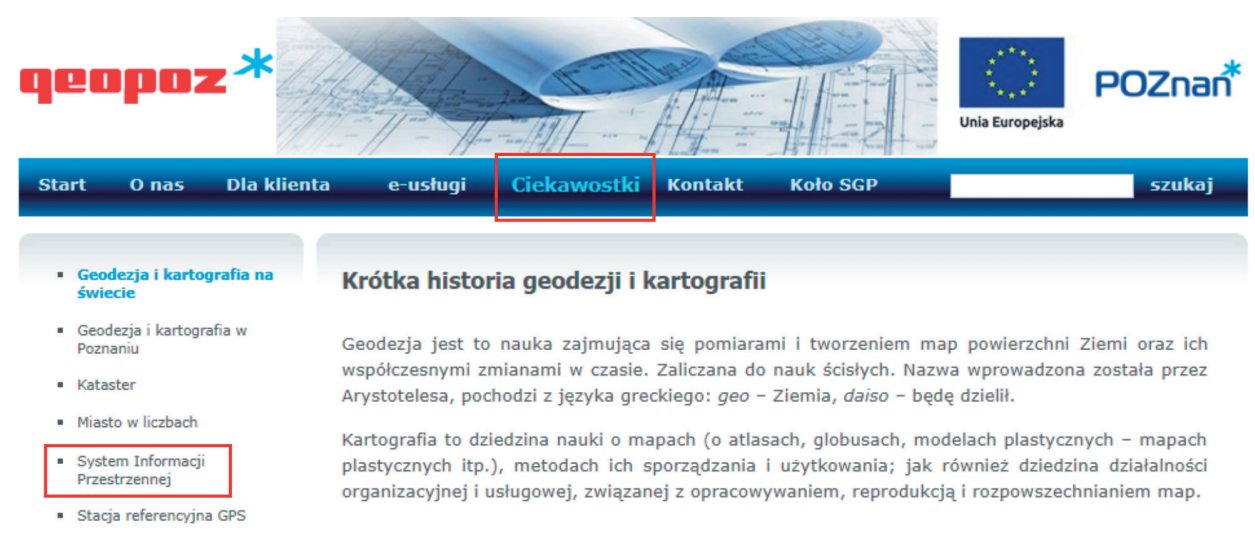

Fig. 6. The website of the Board of Geodesy and the Municipal Cadastre of GEOPOZ

\section{SPATIAL INFORMATION SYSTEM (SIS) IN POZNAŃ}

The SIS in Poznań has been operating since 2003. The purpose of this system is to collect, process and make available spatial data. It includes data presented on about 500 thematic layers. These include property ordinal numbering, road classification, monuments, acoustic maps, public buildings and health care facilities. A part of the data (excluding primarily personal data) is made available at the following address http://sip.geopoz.p/l.

This system is based on iGeoMap software from Geo-System sp. z o.o. To take full advantage of the capabilities of the browser, it is necessary to install the latest version of Java. Access to data is achieved through the active window "Spatial Information System - test version of the browser". From among the available three variants, choose the tab "Maps. Data layers", and then select the "Go to map" button from the "Default configuration" window.

In the opened window (Fig. 7), in its upper part there are, among others, the tabs "Databases" and "Maps". The unfolding of the first of them opens a list of 29 different thematic databases. Contents concerning the presentation of noise in the area of Poznan are included in the "Acoustic map" database, which contains numerous files in .doc and .pdf formats with graphics and text concerning noise research conducted in 2002, 2012 and 2017 and "3D studies".

Unfolding the "Maps" tab allows the user to adopt a different map configuration. After configuration, the main window displays the base map, which is the plan of the city, including:

- street network and address points from the Address System Module of ZGiKM GEOPOZ;

- photogrammetric buildings, green areas, water and traffic areas, tram tracks, railway tracks, streams, ditches, bridges with SIS;

- physiographic names from the national gazetteer. 


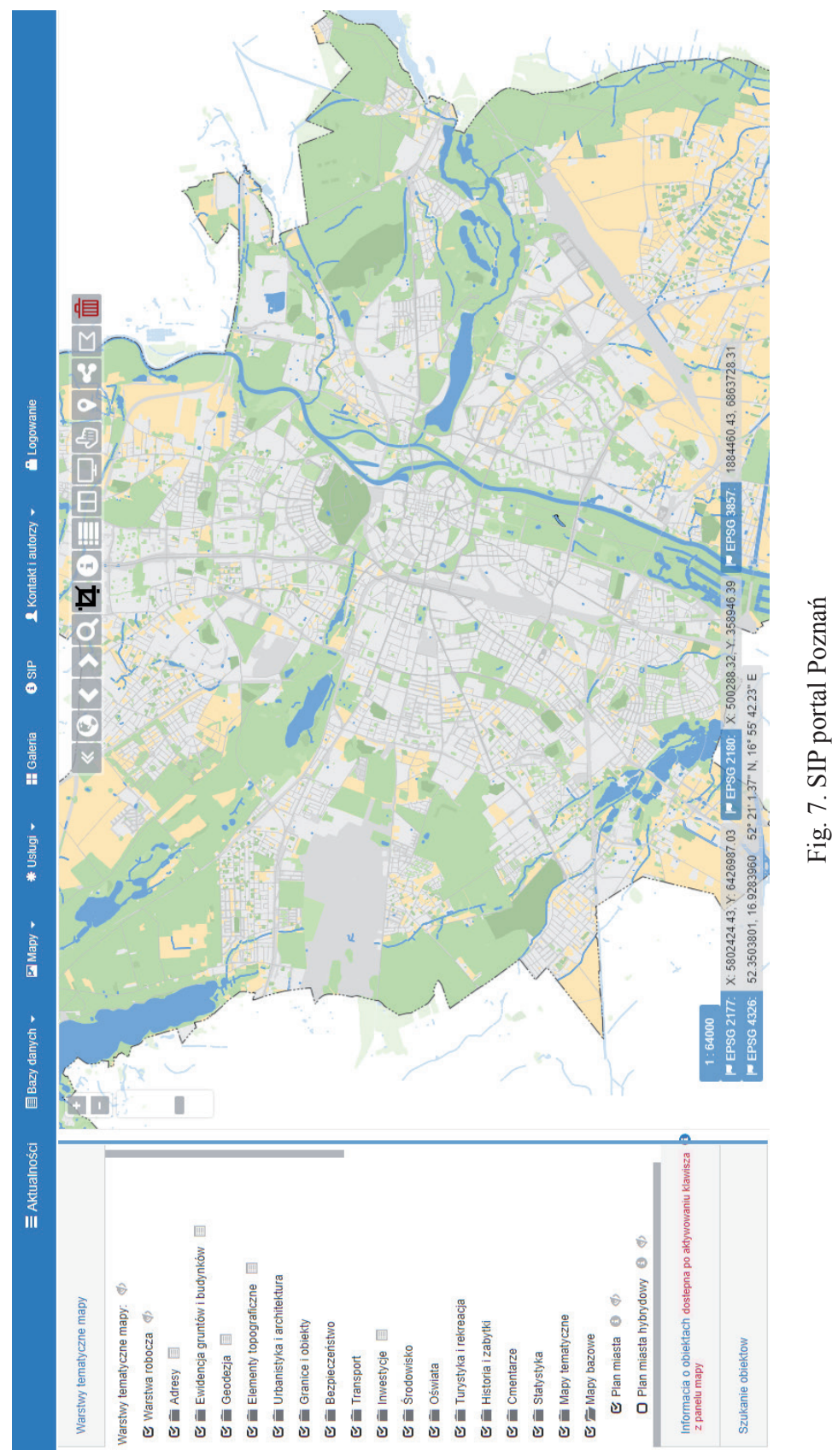


The map can be zoomed in or out in the range from 1:2 048000 to 1:125. The numerical scale of the presented image is displayed at the bottom of the window together with the imaging systems and rectangular flat and geographical coordinates. The location of individual objects can be determined on the basis of four geodetic coordinate systems offered:

- EPSG 2177 - coordinate system 2000 (zone VI);

- EPSG 2180 - coordinate system 1992;

- EPSG 3857 - WGS 84 Web Mercator (projection used in many popular web mapping applications - Google, Bing, OpenStreetMap; also referred to as EPSG 900913 - unofficial layout used in open source/OSGEO projects);

- $\quad$ EPSG 43260 - WGS 84.

The remaining tools (Fig. 8) are located in the bar located at the top of the main window (Fig. 7). They allow for setting the window view, navigating the map, searching for objects, as well as their measurement.

In the left part of the open map window "Thematic layers of the map" are listed. They are composed of 17 thematic main divisions (tab. 1). Their unfolding makes it possible to switch on a given layer.

Visualisations of noise maps are located in the "Environment" tab, where further extensions can be found (tab. 2). Layers 1 to 4 listed in the table refer to information on environmental noise, the

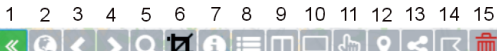

1. Ukryj drzewo warstw

2. Powiększ do granicy miasta

3. Poprzedni widok

4. Następny widok

5. Szukaj

6. Pomiar obiektu

7. Informacja o obiekcie w tabeli

8. Lista warstw do zaznaczania informacji

9. Informacje $z$ warstwy WMS

10. Informacja 'dymek'

11. Selekcja obiektu

12. Punkt

13. Linia

14. Poligon

15. Usuń obiekty wektorowe

Fig. 8. SIP system toolbar first two of which, „Acoustic Map 2012” and „Acoustic Map 2017”, due to the scope and form of the presented content, seem to be the most important. There

Tab. 1. Thematic layers of the map

\begin{tabular}{llll}
\hline 1 & \multicolumn{1}{c}{ Addresses } & 10 & \multicolumn{1}{c}{ Environment } \\
\hline 2 & Registry of land and buildings & 11 & Education \\
3 & Geodesy & 12 & Tourism and recreation \\
4 & Topographic elements & 13 & History and monuments \\
5 & Urban planning and architecture & 14 & Cemeteries \\
6 & Bondaries and objects & 15 & Statistics \\
7 & Security & 16 & Thematic maps \\
8 & Transport & 17 & Base maps \\
9 & Investments & & \\
\hline
\end{tabular}


Tab. 2. Thematic layer of the map: "Environment"

\begin{tabular}{llcl}
\hline 1 & \multicolumn{1}{c}{ Acoustic map 2012 } & 7 & \multicolumn{1}{c}{ Soil } \\
\hline 2 & Acoustic map 2017 & 8 & Mass movements \\
3 & Acoustic measurements & 9 & Mining of minerals \\
4 & Environmental protection program & 10 & Wells \\
& against noise 2013 & 11 & Areas of limited use \\
6 & Forms of nature protection & 12 & Areas exposed to flooding \\
\hline
\end{tabular}

are shortcuts that allow quick access to documentation in the following formats: .pdf, .doc and .xls. The structure of the „Environment” layer is presented in Figure 9.

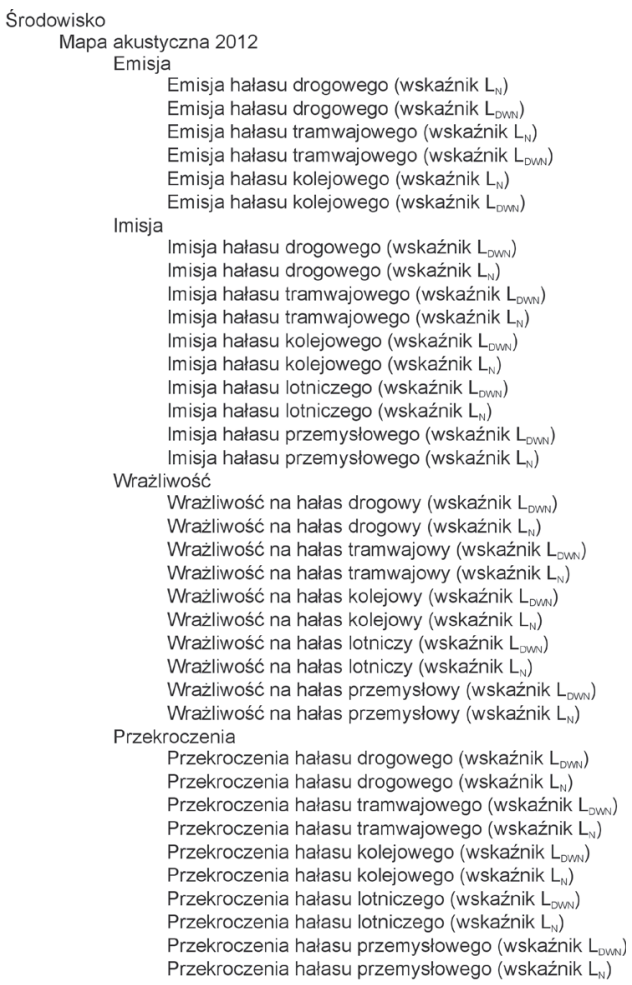

Wrażliwość na halas drogowy (wskaźnik $L_{D W N}$ ) Wrażliwość na hakas drogowy (wskaźnik $L_{N}$ ) Wrażliwość na hałas tramwajowy (wskaźnik $\mathrm{L}_{\mathrm{DWN}}$ ) Wrażliwość na hałas tramwajowy (wskaźnik $L_{N}$ ) Wrażliwość na hakas kolejowy (wskaźnik $L_{\text {Dww }}$ ) Wrażliwość na hałas kolejowy (wskaźnik $L_{N}$ ) Wrażliwość na hałas lotniczy (wskaźnik $L_{\text {oww }}$ ) Wrażliwość na hałas lotniczy (wskaźnik Lv) Wrażliwość na hałas przemysłowy (wskaźnik $L_{\text {Dum }}$ ) Wrażliwość na hałas przemysłowy (wskaźnik $L_{N}$ ) Przekroczenia

Przekroczenia hałasu drogowego (wskaźnik $L_{\text {ow }}$ ) Przekroczenia hałasu drogowego (wskaźnik $L_{N}$ ) Przekroczenia hałasu tramwajowego (wskaźnik $L_{D w w}$ ) Przekroczenia hałasu tramwajowego (wskaźnik $L_{N}$ ) Przekroczenia hałasu kolejowego (wskaźnik $L_{\text {Dww }}$ ) Przekroczenia hałasu kolejowego (wskaźnik $L_{N}$ ) Przekroczenia hałasu lotniczego (wskaźnik $L_{D W N}$ ) Przekroczenia hałasu lotniczego (wskaźnik $L_{\text {, }}$ ) Przekroczenia hałasu przemysłowego (wskaźnik $L_{\text {DuNs) }}$ ) Przekroczenia hałasu przemysłowego (wskaźnik $L_{N}$ )

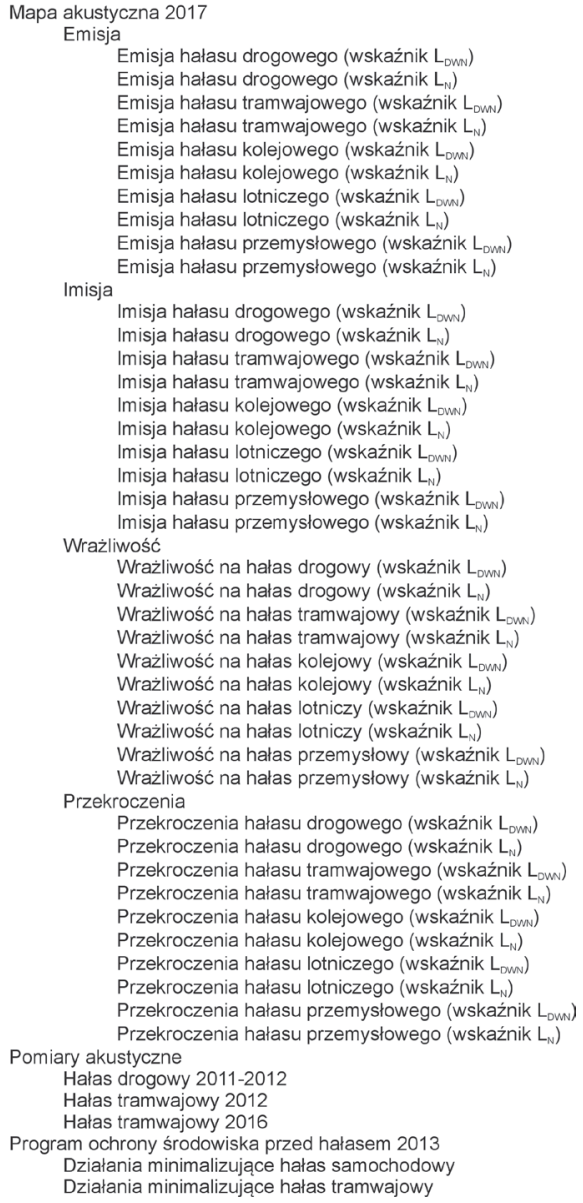

Fig. 9. Structure of the "Environment" layer (noise data) 


\section{ACOUNSTIC MAP 2012}

Available spatial data on the acoustic state of the environment in 2012 include maps of: noise emission (road, tramway and railway), immissions, sensitivity and excesses of road, tramway, railway, air and industrial noise. In accordance with formal requirements, each source is presented on a separate map (layer) for two long-term indicators $\left(L_{\mathrm{DWN}}\right.$ and $\left.L_{\mathrm{N}}\right)$.

Noise emission on the map is visualised by means of coloured line symbols, at which the values of the registered sound levare placed (Fig. 1). Keys are 12 separations covering a range of values from $<35 \mathrm{~dB}$ to $\geq 85 \mathrm{~dB}$, in the intervals of $5 \mathrm{~dB}$ (Fig. 10) and apply to both indicators.

Noise emission is represented by colourful polygons with presented sound level values (Fig. 4). Five separations

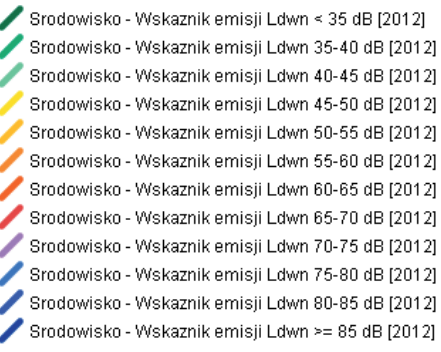

Fig. 10. Noise emission - legend from 2012 (source: SIP Poznań) were applied every $5 \mathrm{~dB}$. The legend varies in terms of the range of values presented (according to formal requirements) depending on the indicator: $L_{\mathrm{DWN}}$ ranges from min. 55-60 dB to max. $>75 \mathrm{~dB}$, and $L_{\mathrm{N}}$ from min. $50-55 \mathrm{~dB}$ to $\max .>70 \mathrm{~dB}$. Fields with lower values were left colourless. The colours used are consistent for each interval of these indices (Fig. 11).
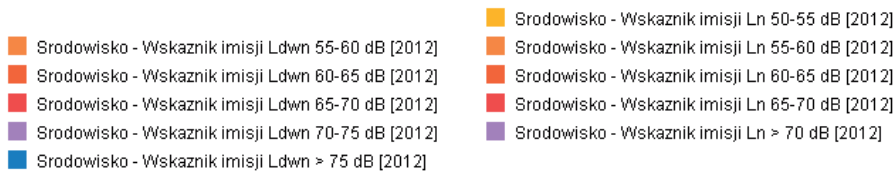

Fig. 11. Imission of noise - legend from 2012: LDWN - on the left, LN - on the right (source: SIP Poznań)

On the noise sensitivity maps colourful regions have been used with the limit values given (Fig. 2). In accordance with the relevant regulation, the area has been divided according to the permissible sound levels applicable in the area (which is directly related to the town planning function of the area): 45, 50, 55, 59, 60, 64, 65, 68 and $70 \mathrm{~dB}$ (Fig. 12). The legend applies to both long-term indicators used.

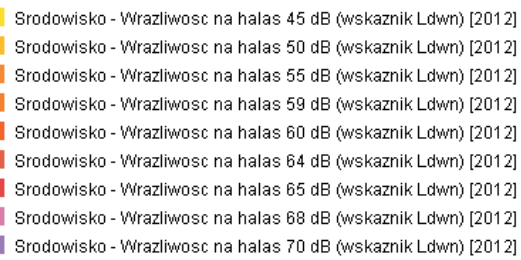

Fig. 12. Sensitivity to noise - legend from 2012 (source: SIP Poznań) 
Srodowisko - Przekroczenia halasu 0-5 dB (wskaznik Ldwn) [2012] Srodowisko - Przekroczenia halasu 5-10 dB (wskaznik Ldwn) [2012] Srodowisko - Przekroczenia halasu 10-15 dB (wskaznik Ldwn) [2012] Srodowisko - Przekroczenia halasu 15-20 dB (wskaznik Ldwn) [2012] Srodowisko - Przekroczenia halasu $>20 \mathrm{~dB}$ (wskaznik Ldwn) [2012]

Fig. 13. Noise violations - legend from 2012 (source: SIP Poznań)
Noise excess maps (Fig. 3) include five colour divisions (polygons) with specified exceedance values, presented in the following ranges: 0-5, 5-10, 10-15, 15-20 and $>20 \mathrm{~dB}$ (Fig. 13). The legend also applies to both long-term indicators.

\section{ACOUSTIC MAP 2017}

Spatial data on the state of the acoustic climate from the latest mapping period in 2017 include a total of 40 images. These are four sets of maps (emission, immission, sensitivity and excess emissions), developed for five different noise sources (road, tramway, rail, air and industrial), showing two long-term indicators $\left(L_{\mathrm{DWN}}, L_{\mathrm{N}}\right)$.

Images of noise emissions vary depending on the source presented and the indicator. The same solutions were used for road, tram and rail noise. $L_{\mathrm{DWN}}$ is expressed in ten colour linear representations, in $5 \mathrm{~dB}$ intervals, in the range of $<35 \mathrm{~dB}$ to $75-80 \mathrm{~dB}$, and $L_{\mathrm{N}}$ includes nine colour linear signatures representing values in the range of $<35 \mathrm{~dB}$ to $70-75 \mathrm{~dB}$. The colours used for each range of both indicators are the same (Fig. 14). For aerospace and industrial sources, six colour surface representations were used. According to formal requirements, $L_{\mathrm{DWN}}$ ranges from $<55 \mathrm{~dB}$ to $>75 \mathrm{~dB}$, and $L_{\mathrm{N}}$ from $<50 \mathrm{~dB}$ to $>70 \mathrm{~dB}$. The colours used for each range of both indicators are the same (Fig. 14). On the map, the colour representation is complemented by a description containing the values of the sound levels.

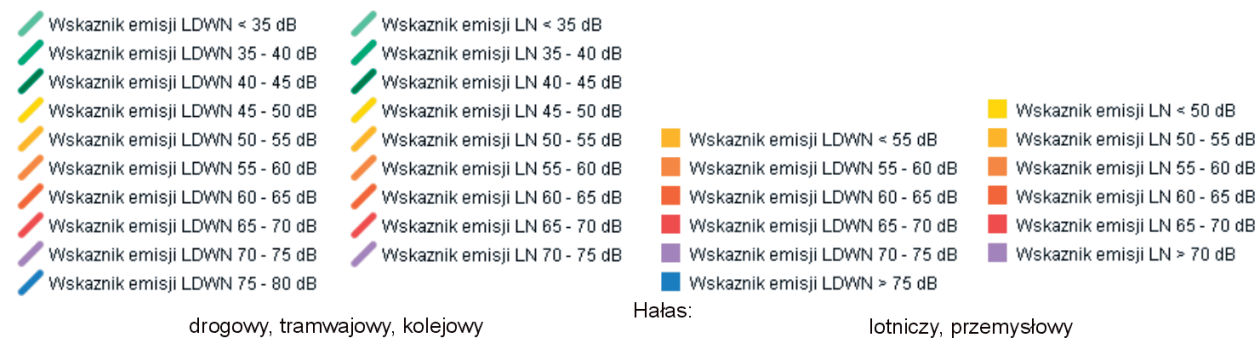

Fig. 14. Noise emission - legend from 2017 (source: SIP Poznań)

The maps of noise immissions differ in terms of the presented values of long-term indicators. For $L_{\mathrm{DWN}}$, six colour regions from $<55 \mathrm{~dB}$ to $>75 \mathrm{~dB}$ (in $5 \mathrm{~dB}$ steps) have been used, while $L_{\mathrm{N}}$ includes six separations in the range from $<50 \mathrm{~dB}$ to $>70 \mathrm{~dB}$. The same solution was used for all sources (Fig. 15). On the 
map, the colour representation is complemented by a description containing the values of the sound levels.

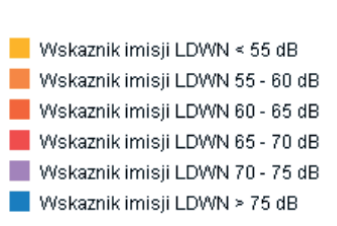

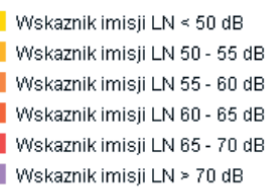

Fig. 15. Imission of noise - legend from 2017 (source: SIP Poznań)

For maps showing the noise sensitivity of areas, a universal legend has been used for both indicators and all sources. This is represented by ten separate colour regions in the range from $40 \mathrm{~dB}$ to $70 \mathrm{~dB}$ ( $5 \mathrm{~dB}$ intervals $)$ - Figure 16 . The colour map is complemented by descriptions containing limit values for areas with a specific town-planning function.

Similarly, a universal legend was used for $L_{\mathrm{DWN}}$ and $L_{\mathrm{N}}$ indicators (Fig. 17). They are represented by five coloured polygons together with which excess values are given in the following ranges: 0-5, 5-10, 10-15, 15-20 and >20 dB.

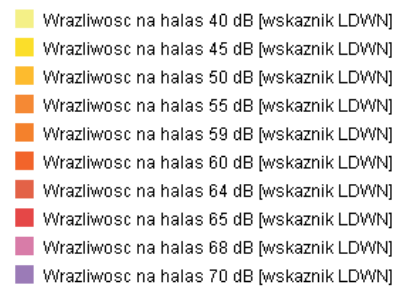

Fig. 16. Sensitivity to noise legend from 2017 (source: SIP Poznań))

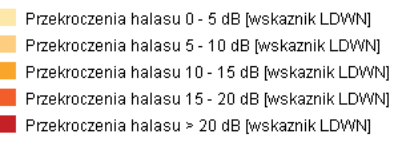

Fig. 17. Noise violations legend from 2017 (source: SIP Poznań)

\section{D IMAGES}

According to the Regulation of 1 October 2007 (Journal of Laws 2007), from 2012 the method of presentation of Internet acoustic maps should enable three-dimensional imaging on a scale not exceeding 1:1,000. In the case of the Spatial Information System in Poznań, access to this type of data is achieved by selecting the "3D studies" option in the "Databases" tab. There are 127 records contained here, 38 of which refer to the three-dimensional presentation of the distribution of noise immissions on the facades of buildings in selected areas of the city in 2017 (19 visualisations for $L_{\mathrm{DWN}}$ and $L_{\mathrm{N}}$ indicators). Only road noise 
images are available. An orthophotomap was used in the background of the presentation (Fig. 18).

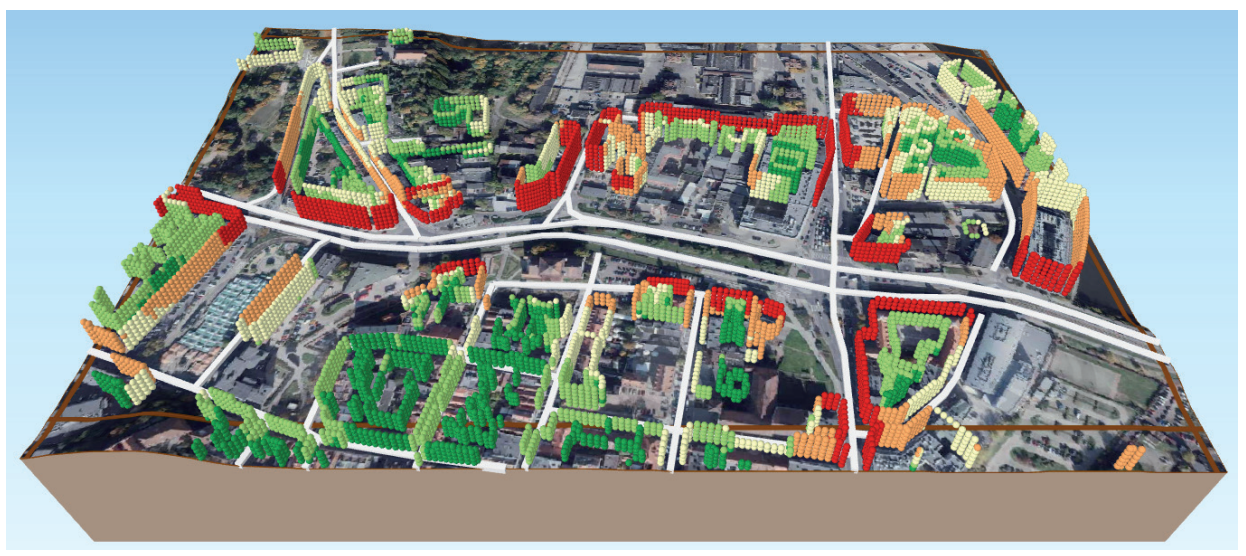

Fig. 18. Road noise immission (LDWN indicator) - 3D demonstration (source: SIP Poznań)

\section{SUMMARY - ADVANTAGES AND DISADVANTAGES OF THE SIS PRESENTATION}

Noise must be mapped every five years and information on the acoustic state of the environment should be made available to the public user in an accessible form. These obligations result directly from the provisions of the Environmental Protection Law Act.

In Poznań, guidelines concerning access to spatial information are implemented through the Spatial Information System of the Geodesy and Urban Cadastre Authority GEOPOZ. With regard to noise, the following maps are presented here: emissions, immissions, sensitivity of areas and excesses of limit values for sound levels. Identified sources of urban noise (road, tramway, railway, aviation, industrial) are presented separately on separate maps (thematic layers). The state of the acoustic environment is expressed by two long-term indicators $\left(L_{\mathrm{DWN}}\right.$ and $\left.L_{\mathrm{N}}\right)$. Such presentation of thematic data is in line with the applicable requirements of the legal documents.

In terms of access to data concerning the acoustic aspect of the environment, the SIS meets the formal conditions to the most basic extent. Using the portal is undoubtedly very convenient, and the data are presented in an attractive form. However, finding the right information requires some patience and perseverance from the user, as discussed in the introduction. Unfortunately, the user also has to take into account certain limitations of the system.

The main problem in the visualisation is the simultaneous display of the values of both $L_{\mathrm{DWN}}$ and $L_{\mathrm{N}}$ indicators, due to the overlapping of one of the 
layers. Theoretically, it is unwarranted, as $L_{\mathrm{DWN}}$ refers to the time of the whole day ( $24 \mathrm{~h}$ ), while $L_{\mathrm{N}}$ only to the time of the night $(8 \mathrm{~h})$, so there is no need to simultaneously view both indicators, but these presentations are to serve a wide audience, who may not have detailed knowledge about the methods of presenting the phenomenon. The installed tool for switching on the transparency of the selected thematic layer gives the possibility to view more data and their relative legibility, but it also causes a change in the perception of color, which in turn may cause a misinterpretation of the presented content.

Another noticeable problem is the way of presenting on the 2017 noise immission maps of the ranges corresponding to the lowest values, i.e. $L_{\mathrm{DWN}}$ below $55 \mathrm{~dB}$, and for $L_{\mathrm{N}}$ below $50 \mathrm{~dB}$. In the legend, colour separations (yellow) are used for them, while on the map these areas remain colourless. This may give rise to interpretative doubts as to whether the area which remains colourless has sound level values lower than $55 \mathrm{~dB}$ or $50 \mathrm{~dB}$, or whether these are areas for which no recorded sound level values have been determined.

With regard to three-dimensional presentations, a very visible shortcoming of the images offered by SIS is the legend. It does not display correctly, which significantly reduces cognitive capabilities. The explanations can only be read in their entirety after saving the image to another file. The range of presented values falls within five intervals which are not equal (which is not in accordance with formal requirements) - for the $L_{\mathrm{DWN}}$ indicator these are: (1) $0,0-46,8$; (2) $46,8-52,7$; (3) $52,7-59,3$; (4) 59,3-66,2; (5) 66,2-77,6 and for $L_{\mathrm{N}}$ : (1) 0,0-38,7; (2) $38,7-44,8$; (3) $44,8-51,5$; (4) $51,5-58,4$; (5) $58,4-71,3$. Thus, there are different sizes of intervals and their range is different, which is not explained in the text or explanations. However, in both cases the colours of subsequent intervals have been preserved. This also creates a cognitive dissonance, as the colours correspond to other noise ranges (values). If the legend is not displayed, it is therefore completely impossible to identify the acoustic situation (for the whole day and night) with the help of the colours alone.

The advantage of the images is that they can be rotated and viewed from different angles. Unfortunately, this tool does not work very precisely. Moreover, this functionality (it must be admitted that it is very attractive from the user's point of view) is not signalled in any way, as is the possibility of zooming in or out of the image. There is also a lack of basic information about the scale of the viewed image and the format of the units in which the data are presented. This requires the user to have a certain amount of knowledge about the indicators used to describe the acoustic climate - and these are not, however, common competences.

In summary, access to information on the acoustic state of the environment is achieved to the minimum required by formal provisions. However, it is difficult to talk about the universality of access to data, as finding the right content requires increased involvement of the user, which, unfortunately, may sometimes 
lead to discouragement and, consequently, to abandoning the search for information concerning this aspect of the environment. Some of the visualisation elements and available tool options should undoubtedly be improved in order to make them more readable, encouraging and intuitive for the non-professional user.

\section{REFERENCES}

Allen R.W., Davies H., Cohen M.A., Mallach G., Kaufman J.D., Adar S.D., 2009: The spatial relationship between traffic generated air pollution and noise in 2 US cities. Environmental Research, 109: 334-342.

Babisch W., 2005: Noise and health. Environmental Health Perspectives, 113, 1: 14-15.

Czeskin M.S., 1986: Człowiek i hałas. Państwowe Wydawnictwo Naukowe, Warszawa.

Dziennik Ustaw, 2007: Rozporządzenie Ministra Środowiska z dnia 1 października 2007 roku w sprawie szczegółowego zakresu danych ujętych na mapach akustycznych oraz ich układu i sposobu prezentacji (Dz.U. z 2007 r., Nr 187, poz. 1340).

Dziennik Ustaw, 2013: Ustawa z dnia 27 kwietnia 2001 roku - Prawo ochrony środowiska (Dz.U. z 2001 r. Nr 62, poz. 627 i Dz.U. z 2013 r. poz. 1232 z późn. zm.).

END, 2002: Environmental noise directive. Directive 2002/49/EC relating to the assessment and management of environmental noise. The European Parliament and of the Council, Brussels.

Garcia A., 2001: Environmental Urban Noise. Wentworth Institute of Technology Press, Boston.

Goines L., Hagler L., 2007: Noise pollution: a modern plague. Southern Medical Journal, 100: 287-294.

Halama G., Berkemann J., 2009: Hałas środowiskowy - Dyrektywa 2002/49/WE Parlamentu Europejskiego i Rady. Dziennik Urzędowy Unii Europejskiej z dnia 25 czerwca 2002 roku.

King E.A., Rice H.J., 2009: The development of a practical framework for strategic noise mapping. Applied Acoustics, 70: 1116-1127.

Komisja Europejska, 2014: The EU Policy on Environmental Noise. http://ec.europa.eu/environment/noise/home.htm

Kompała J., 2005: Mapy akustyczne jako narzędzia zarządzania klimatem akustycznym na terenach zurbanizowanych. Prace Naukowe Wyższej Szkoły Zarządzania Ochroną Pracy w Katowicach. Wydawnictwo WSZOP, Katowice, 5: 74-84.

Koszarny Z., 1999: Wpływ hałasu na zdrowie człowieka. Ekopartner.

Koszarny Z., Szata W., 1987: Narażenie ludności Warszawy na hałas uliczny cz. I i II. Roczniki Państwowego Zakładu Higieny, nr 1 i 2.

Leśnikowska-Matusiak I., Wnuk A., 2014: Wpływ hałasu komunikacyjnego na stan środowiska akustycznego człowieka. Wydawnictwo Instytutu Transportu Samochodowego, 3: 37-62.

Stevens M., 2012: Community memories for sustainable societies: The case of environmental noise. VUB-Press, Brussels.

WHO, 2005: Occupational and community noise. World Health Organization Publication.

Zannin P.H.T., Ferreira A.M.C., Szeremetta B., 2006: Evaluation of noise pollution in urban parks. Environment Monitoring Assessment, 118: 423-433. 